\section{Acknowledgments}

We thank Dr R. Whitelaw and Dr A. Crispin for help with interpretation of the radiographs.

\section{References}

British Medical Journal (1971) Leading Article. Haemorrhage in the newborn, iv, 1.

BoyD, J.E. (1967) Disseminated fibrin thromboembolism among neonates dying within $48 \mathrm{hr}$ of birth. Archives of Diseases in Childhood, 42, 401.

Bryant, G.M., Gray, O.P., Fraser, A.J. \& Ackerman, A. (1970) Fate of surviving low birth weight infants with coagulation deficiencies on the first day of life. British Medical Journal, iv, 707.

CATHRo. D.M. (1969) The adrenal cortex and medulla. In: Paediatric Endocrinology (Ed. by D. Hubble), p. 275. Ch. 5. Blackwell Scientific Publications: Oxford.

Chadd, M.A., Elwood, P.C., Grey, O.P. \& MaXworthy, S.M. (1971) Coagulation defects in hypoxic full-term newborn infants. British Medical Journal, iv, 516.
Chessells, J.M. \& Wigglesworth, J.S. (1970) Secondary haemorrhagic disease of the newborn. Archives of Diseases in Childhood, 45, 539.

CrisPIN, A. (1972) Medullary necrosis in infancy. British Medical Bulletin, 28, 233.

Gross, S. \& Melhorn, D.K. (1971) Exchange transfusion with citrated whole blood for disseminated intravascular coagulation. Journal of Pediatrics, 78, 415.

Verhagen, A.D., Hamilton, J.P. \& Genel, M. (1965) Renal vein thrombosis in infants. Archives of Diseases in Childhood, 40, 215.

Whaun, J.M., Ormson, J. \& Oski, F.A. (1971) One year's experience with disseminated intravascular coagulation in a children's hospital. Programme American Pediatric Society, p. 6. Quoted by F. A. Oski \& J. L. Naiman, 1972, Hematologic Problems in the Newborn (Ed. by A. J. Scheffer). Second edition, ch. 8, p. 286. Saunders: Philadelphia.

\title{
The treatment of priapism by corpus-saphenous by-pass
}

\author{
R. J. E. FolEY* \\ F.R.C.S.
}

\author{
L. R. DE JODE \\ M.S., F.R.C.S.
}

Whipps Cross Hospital, Leytonstone, London

\section{Summary}

Two cases of priapism treated by corpus-saphenous by-pass are presented. Priapism responded to treatment successfully in both cases. Satisfactory erection and sexual intercourse followed 6 weeks after operation in one case. The second patient failed to have further erections. It was thought that this was due to the length of time ( 6 weeks) between onset of priapism and operation.

\section{Introduction}

Priapism is a pathologically prolonged erection not associated with sexual desire and usually painful. Priapism is due either to increased neurogenic stimulation or more usually clotting in the corpora cavernosa and prostatic plexus and obstruction of the venous outflow of the penis (Hinman, 1960). Thus in 1964 Grayhack et al. devised a method of diverting the venous outflow via a long saphenous shunt to the femoral vein. As the corpora cavernosa communicate distally with each other a unilateral shunt is usually sufficient. In this paper, two cases of priapism treated by corpus saphenous by-pass are presented.

* Present address: The Royal Free Hospital, Pond Street, Hampstead, London NW3.

\section{Case reports}

Case 1. A 31-year-old Negro was admitted to hospital with a 36-hr history of priapism. For 2 weeks before admission he had had prolonged erections on waking in the morning. Thirty-six hours before admission he had indulged in prolonged sexual intercourse with his wife. Since then his penis had been painful and erect. He had had a similar episode 7 years previously when he had had an erection for 1 day. This had resolved spontaneously.

Examination revealed a well built Negro with a temperature of $100^{\circ} \mathrm{F}$. His penis was turgid, erect and very hard and measured some 8 in. He had a tender, palpable lymph node in the left groin. Investigation revealed $\mathrm{Hb} 68 \%$; WBC 6000 with a normal differential; ESR $135 \mathrm{~mm} / \mathrm{hr}$. Sickle test was negative.

$\mathrm{He}$ was initially treated with streptokinase $1,200,000$ units i.v. as a loading dose and 6000 units 6-hourly for $24 \mathrm{hr}$. His penis remained erect. Right corpus cavernosum by-pass was then performed. At the end of the procedure the penis was softer and 1 in shorter. During the first $48 \mathrm{hr}$ of the postoperative period the penis was compressed intermittently, using a child's sphygmomanometer cuff. During the ensuing period his penis became smaller and softer still, and his temperature and ESR 
returned to normal. Recovery was uneventful. Examination of the graft 6 days postoperatively with the Doppler ultrasound revealed an arterial-like sound which was much increased by squeezing the penis.

Six weeks postoperatively be recommenced sexual relations with his wife and when seen in follow-up 1 year later was having sexual intercourse 3 times per week, although his wife said that his penis never became quite as hard as before the operation.

Case 2. A 58-year-old retired Kenyan Asian was admitted with a 6-week history of priapism. In spite of the fact that he had two wives at the time, priapsim had occurred spontaneously. He had been admitted to hospital while on a return trip to Kenya and there had been treated with cold lotions, anticoagulants and spinal anaesthesia, all to no avail. He returned to England and was admitted to Whipps Cross Hospital.

Examination revealed a fit man, temperature $98.4^{\circ} \mathrm{F}$, pulse 80 , and the only abnormal finding was a tender, erect penis. Right corpus saphenous bypass was carried out and his penis became flaccid and has remained so. His postoperative recovery was complicated by a wound infection.

\section{Discussion}

Medical treatment of priapism has been of little success. Callaway (1824) reported cold lotions, leeches, emetics and narcotics to be of no avail. Anticoagulants have not helped and indeed priapism has occurred in patients on anticoagulants (Grace and Winter, 1968; Eadie and Brock, 1970). Hypotensive therapy (Ulm, 1959) has been useful but not regularly successful. Streptokinase failed to relieve priapism in one of our cases.

Surgical treatment has an equally long history. Callaway (1824) incised the corpus cavernosumrelieving the priapism but impotence resulted. In 1960 Burt, Schirmer and Scott successfully treated a patient with priapism by pudendal ligation. To date, Grayhack's operation of corpus saphenous shunt has met with the greatest success. Of the cases so far reported, all twenty have had their priapism relieved and most (fourteen) have returned to normal sexual function (see Table 1). Where there has been a failure to re-establish erection there has usually been a delay in performing corpus cavernosum saphenous by-pass, and fibrosis in the corpora has occurred.

The operation has been complicated by pulmonary embolus in one case (Kandel, Bender and Grove, 1968). Fortunately, this was not fatal and a satis- factory result was obtained. The only other complication reported is a wound infection which occurred in one of our patients.

TABLE 1. Results of corpus-saphenous by-pass in the treatment of priapism

\begin{tabular}{|c|c|c|c|c|}
\hline Year & Author & $\begin{array}{l}\text { No. of } \\
\text { cases }\end{array}$ & $\begin{array}{l}\text { Priapism } \\
\text { relieved }\end{array}$ & $\begin{array}{c}\text { Potent } \\
\text { afterwards }\end{array}$ \\
\hline 1964 & Grayhack et al. & 1 & 1 & 1 \\
\hline 1966 & Garrett and Rhamy & 5 & 5 & $\begin{array}{c}4 \\
\text { (1 failed } \\
\text { to attend } \\
\text { follow-up) }\end{array}$ \\
\hline 1968 & Grace and Winter & 2 & 2 & 2 \\
\hline 1968 & Kandel et al. & 1 & 1 & 1 \\
\hline 1969 & Martinez et al. & 1 & 1 & 1 \\
\hline 1969 & $\begin{array}{l}\text { Martin, Schapiro and } \\
\text { Burkholder }\end{array}$ & 3 & 3 & 2 \\
\hline 1970 & Eadie and Brock & 2 & 2 & 0 \\
\hline 1972 & $\begin{array}{l}\text { Chi Meen Lee, } \\
\text { Kandzari and Milan }\end{array}$ & 3 & 3 & $\begin{array}{c}2 \\
\text { (1 failed } \\
\text { to attend } \\
\text { follow-up) }\end{array}$ \\
\hline \multirow[t]{2}{*}{1974} & This paper & 2 & 2 & 1 \\
\hline & Total & 20 & 20 & 14 \\
\hline
\end{tabular}

\section{Acknowledgments}

We would like to thank Mr D. Lang Stevenson under $\delta$ whose care one of the patients was admitted.

\section{References}

Burt, F.B., Schirmer, H.K. \& ScotT, W.W. (1960) A new concept in the management of priapism. Journal of Urology, 83, 60.

Callaway, T. (1824) Letter. London Medical Repository, 21, 286.

Chi Meen Lee, M.P., Kandzari, S.J. \& Milan, D.F. (1972) Priapism: treatment by corpus cavernosum saphenous vein anastomosis. Annals of Surgery, 175, 279.

EADIE, D.C.A. \& BROCK, T.P. (1970) Corpus saphenous bypass in the treatment of priapism. British Journal of Surgery, 57, 172.

GARRETT, R.A. \& RHAMY, D.E. (1966) Priapism, management with corpus saphenous shunt. Journal of Urology, 95, 66.

GRACE, D.A. \& WINTER, C.C. (1968) Priapism: an appraisal of management of 23 patients. Journal of Urology, 99, 301.

GrayhaCK, J.T., McCullough, W., O'ConNOR, W.J., JR \& TRIPPEL, O. (1964) Venous by-pass to control priapism. Investigative Urology, 1, 509.

Hinman, F., JR (1960) Priapism: reasons for failure of therapy. Journal of Urology, 83, 420.

Kandel, G.L., Bender, L.I. \& Grove, J. (1968) Pulmonary embolism: a complication of corpus saphenous shunt for priapism. Journal of Urology, 99, 196.

Martin, D.C., Schapiro, A. \& Burkholder, G. (1969) Corpus cavernosum-saphenous vein anastomosis for priapism. Journal of Urology, 102, 221.

Martinez, H., Sharma, T.C., MacDonald, G. \& Smyth, N.P.D. (1969) Operative management of priapism secondary to sickle cell trait. Archives of Surgery of Chicago, 98, 81.

ULM, A.M. (1959) The treatment of primary priapism with Arfonad. Journal of Urology, 81, 291. 